\title{
Should Transit Serve the CBD or a Diverse Array of Destinations? A Case Study Comparison of Two Transit Systems
}

Jeffrey R. Brown and Gregory L. Thompson

Florida State University

\begin{abstract}
This analysis seeks to understand the relative efficacy of two classes of policies intended to increase the ridership and productivity of public transit service. One seeks to improve transit effectiveness by freezing transit service in the older parts of metropolitan areas, such as the CBD and surrounding dense neighborhoods, where growth is to be directed. The other seeks to connect employment and population, wherever it locates, as directly as possible by transit routes. The case study compares transit performance in two regions that pursue these two service approaches. The analysis shows that the transit system that seeks to serve all jobs carries almost 400 percent more ridership per capita than does the transit system that seeks to serve primarily $C B D$ jobs, while each bus mile operated in the dispersed transit system carries about 35 percent more passengers than each bus mile in the CBD-focused transit system.
\end{abstract}

\section{Introduction}

This case study seeks to understand the relative efficacy of two classes of policies intended to increase the ridership and productivity of public transit service. One 
class of policies seeks to improve transit effectiveness by freezing transit service in the older parts of metropolitan areas. It is thought that higher densities of population and employment and the presence of pedestrian amenities in older areas induce higher levels of transit demand. Policy should attempt to direct population and employment growth to such areas, particularly around transit stops. The other class of policies seeks to connect employment and population, wherever it locates, as directly as possible by transit routes. The thrust of transit development of this second category of policies is in the newer rather than older parts of metropolitan areas, because it is in the newer areas that most population and employment growth is located.

The analysis contrasts transit development objectives and transit performance in Broward County, Florida, with those in Tarrant County, Texas. Transit development policy in the two counties is comparable, because both counties are similar in population size and growth rates, and both are situated similarly in their respective metropolitan areas, which are Miami and Dallas-Ft. Worth. Their transit systems also are both the second largest in their respective metropolitan areas. They differ primarily in the fact that Tarrant County contains a traditional CBD, and transit is organized around it. Employment in other parts of the county, which are much newer, is overlooked as a transit destination. Transit in Broward County serves all employment. Broward County lacks a CBD and is one vast suburb that developed during the auto era. Transit development objectives in Broward County generally reflect the second category of policies; those in Tarrant County generally reflect the former.

\section{The Debate Over How Transit Should be Organized}

The conventional wisdom is that transit works best when it focuses on serving the CBD commute market (Ferreri 1992, Meyer and Gomez-Ibanez 1981, Pisarski 1996, Taylor 1991). One researcher found that CBD employment is an important predictor of transit patronage (Hendrickson 1986); another found that employment decentralization explained transit patronage decline (Gomez-lbanez 1996). The implication is that transit agencies should structure their service to feed the $\mathrm{CBD}$ and provide high quality service to that destination, because, as the literature would suggest, that is where riders wish to travel. An agency decision to serve other destinations, particularly those dispersed throughout the suburbs, is criticized for being an inefficient use of public subsidy (Taylor 1991) and for resulting in low service productivity (Ferreri 1992, Meyer and Gomez-lbanez 1981). 
A problem with all of these studies is that they did not examine the results of transit systems that explicitly attempted to serve suburban employment. Their approach was to track the patronage of CBD-centered transit systems that sent routes ever-farther into the suburbs in attempts to lure passengers to jobs in the CBD. Brown and Thompson (2008), however, found that extension of coordinated rail/bus transit service to jobs in suburban Atlanta resulted in patronage growth, whereas growth of jobs in other parts of Atlanta not served by transit resulted in patronage decline. Controlling for numerous variables in a cros- sectional study of transit patronage in the U.S., Brown and Neog (2007) found that CBD employment had no effect on patronage growth. This study joins the debate by explicitly comparing transit performance in two regions. In one, serving CBD employment is the major objective of transit policy. In the other, serving all employment is the major objective of transit policy.

\section{The Settings}

Broward County, Florida, served by Broward County Transit (BCT), lies immediately north of Miami-Dade County, in which lies the city of Miami. Tarrant County, Texas, served by The T, lies immediately west of Dallas County, home to the city of Dallas. Broward and Tarrant counties have similarly-sized populations that have grown at comparable rates (see Figure 1). They differ in one important way, however: Tarrant County contains a large, traditional central business district (downtown Ft. Worth) that emerged in the late 19th century. An electric streetcar system and an electric interurban line running between $\mathrm{Ft}$. Worth and Dallas evolved in symbiosis with downtown Ft. Worth. Broward County has no traditional central business district of the magnitude of Ft. Worth. It does have small downtowns (the largest of which is Ft. Lauderdale) that grew around stations on the Florida East Coast Railroad that linked Miami to Jacksonville in the 1890s, running near the coast, but well into the 20th century, Miami remained as the only traditional central business district of the region.

$\mathrm{BCT}$ and The T are the second largest transit systems in their respective metropoli$\tan$ areas. Both are the primary transit providers in the counties they serve, and they connect with transit systems in other counties. BCT buses enter northern MiamiDade County where they connect with Miami-Dade Transit (MDT) buses (see Map 1). They also connect with Palm Tran buses in southern Palm Beach County. About half of BCT bus routes also cross tracks of Tri-Rail. Tri-Rail, operated by the South Florida Regional Transportation Authority, is a suburban passenger service using 


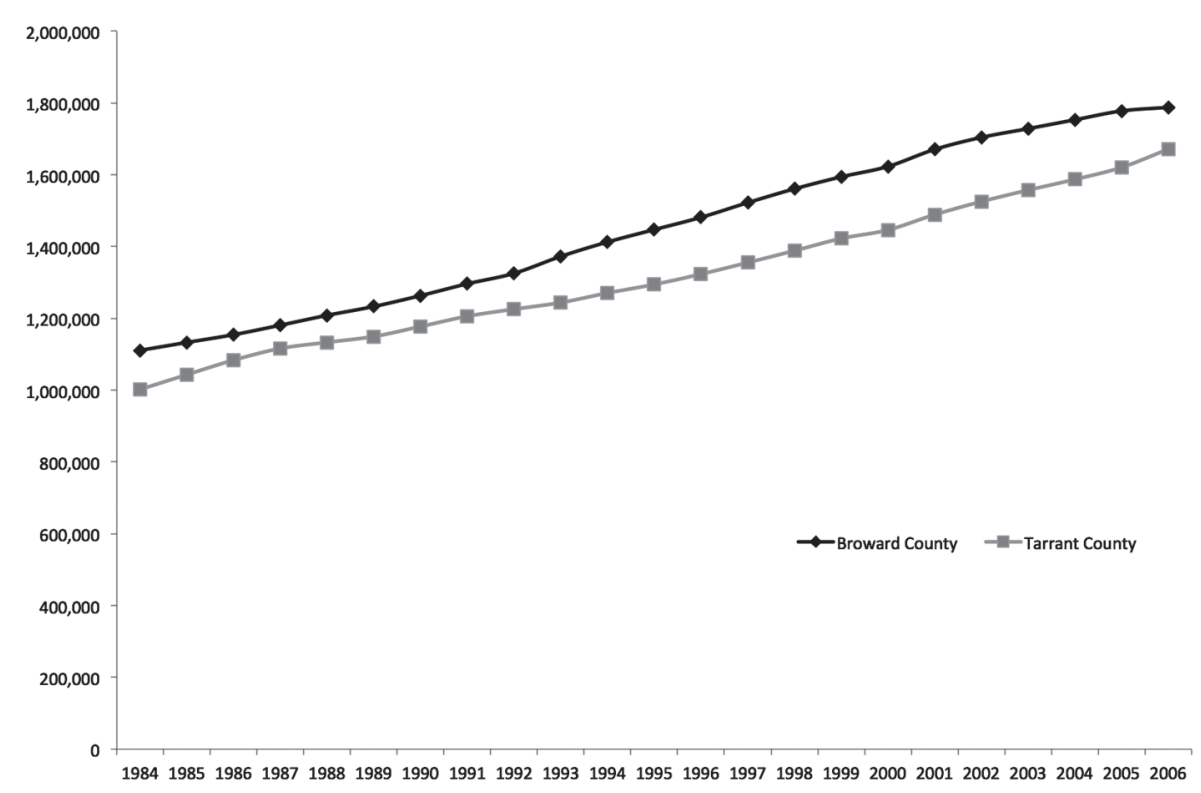

\section{Figure 1. Broward and Tarrant Counties Have Similar Populations and Growth Rates, 1984-2006}

tracks on the old Seaboard Air Line Railroad, five or six miles inland of the Florida East Coast Railroad. Tri-Rail trains connect Miami to West Palm Beach, stopping at seven stations within Broward County. Tri-Rail currently runs trains hourly in both directions during the week day. These are supplemented by additional trains during peak periods. Service is every two hours on weekends. During early 2008, Tri-Rail boarded about 14,000 passengers per day, with a little more than a third of those boarding at Broward County stations. While the Broward County train boardings are substantial, there is virtually no transfer activity between BCT buses and Tri-Rail trains. Tri-Rail passengers wishing to board BCT buses pay 50 cents to do so, less than half the normal bus fare of $\$ 1.25$ (as of October 2007); BCT passengers wishing to transfer to Tri-Rail trains pay the full Tri-Rail fare (which is zoned depending upon distance traveled) but get to board BCT for free. Transfers between BCT buses are free. Because of the absence of bus-rail transfer activity, this study focuses on Broward County buses. 


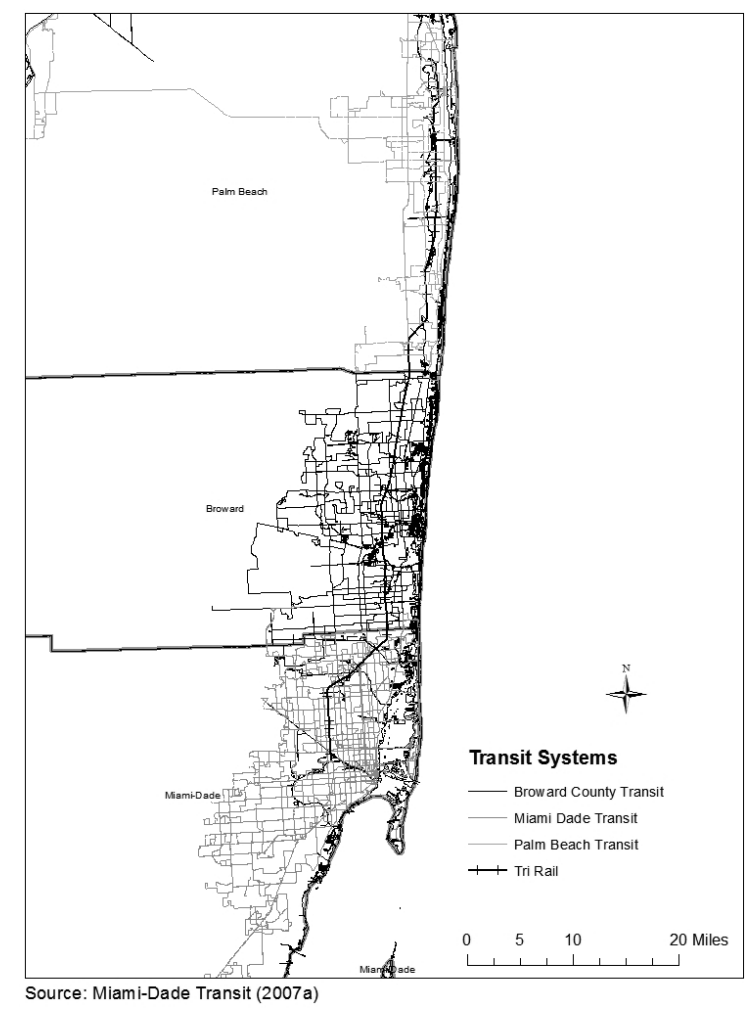

\section{Map 1. Both Transit Systems Fit into Their Regional Contexts Similarly: BCT Adjacent to Miami-Dade Transit and Tri-Rail}

The $\mathrm{T}$ is more insulated from other bus systems in its metropolitan area (see Map 2), but it is somewhat better integrated with commuter rail service, known as Trinity Railway Express (TRE). TRE began limited service from Dallas Union Station (where it connects with Dallas Area Rapid Transit [DART] light rail trains) to a station south of the Dallas-Ft. Worth airport in 1996; in 2001, TRE service was extended westward into the Ft. Worth central business district, where it connects with The $T$ buses in a large multi-modal transit terminal. TRE trains now run roughly on an hourly headways Monday through Saturday, with more service during peak times. TRE attracted roughly 9,000 passengers per day in March 2008, rising to more than 12,000 passengers per day in July 2008 as gas prices rose. The T and DART share ownership of TRE, and there are free transfers between The T buses and TRE trains. There is some amount of transfer activity between The T buses and TRE trains, but not much. TRE serves few trips within Tarrant County, so this study focuses on The T. 


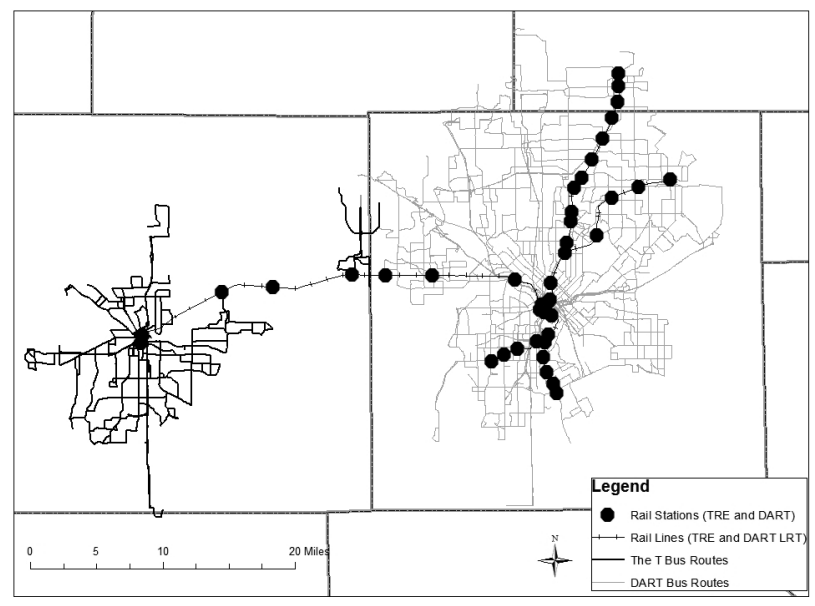

Source: North Central Texas Council of Governments (2007)

\section{Map 2. The T Adjacent to Dallas Area Rapid Transit and Trinity Rail Express Transit Development in Broward County}

Prior to public involvement in the provision of transit service in Broward County, two private operators offered service in the county. One ran several routes focused on the Ft. Lauderdale downtown; the other ran several routes focused on the Hollywood downtown. Our agency contact person characterized both systems as having skeletal, circuitous routes with hourly headways. He called them "spaghetti networks" that attempted to go "where the riders are" - that is, routes wandered through neighborhoods where riders lived. On the other end, routes served the beaches and were designed to carry domestic employees who worked in condos. Our agency contact person further characterized the systems as "unreliable and inefficient."

BCT was organized to take over the two private systems in the mid-1970s. Originally, it was a division in the Broward County Office of Transportation but later was moved to Broward County Community Services, reflecting a vision of transit as being a social service. Sometime later, BCT was moved back to the Office of Transportation, where it remains today. At first, BCT expanded upon the route structure that already was in place. One improvement was the creation of an overlay of express bus routes that ran from various parts of the county to downtown Ft. Lauderdale and to Miami International Airport.

Our agency contact person, who joined the system as that time as a bus driver, said that the system carried few riders. Even the modest ridership that the express lines initially attracted dwindled from year to year. Low ridership on all of its services 
prompted $\mathrm{BCT}$ management to reflect upon how it might do things differently. Service to Miami International Airport was suspended when Eastern Airlines shut down. The director of the system at the time, Houston Miller, determined that the system needed to be gridded, but that it should be changed over incrementally. The process began in 1980 with Operation Changeover. Base headways were reduced from 60 to 30 minutes on what were termed "mainline routes." Headways were shortened due to recognition that a grid would require many passengers to transfer to complete their trips; hourly headways were felt to be too long for passengers to wait at transfer points.

The gridding of the system happened over a period of 10 to 15 years, beginning in 1980. For many years, some routes still had deviations to serve destinations such as condo complexes. All express routes were gone by the late 1980s. Our agency contact person said that BCT formed its routing decisions with studies by the USF Center for Urban Transportation Research (CUTR) and the National Transit Institute (NTI) that compared BCT to other transit agencies. BCT also used common sense. Broward County has a grid pattern for its arterial roads, so the move to grid transit network seemed logical. Our agency contact person also reported that BCT received positive feedback from its early route straightening that gave it confidence to continue with the process. After BCT did so, they experienced increased ridership. Population growth also was pointed to as a factor influencing steady increase in ridership from 13 million trips in 1984 to around 40 million today.

The busiest bus service today operates on U.S. 441, a high-speed, heavily trafficked multi-lane arterial highway that runs through the middle of the built-up part of the county in a north-south orientation. Two routes operate on this road from one end of the county to the other. Route 18 provides local service on 15-minute headways. "The Breeze" provides limited stop service, stopping every mile or so to interchange passengers with buses on busy east-west routes. Loads are heavy, and BCT uses articulated buses to handle them. The U.S. 441 routes serve no downtown but do serve numerous strip malls, regular malls, and big box stores. Apartment complexes generally are only one to two blocks away on either side. On the south end, the U.S. 441 routes connect with MDT buses. The Breeze picks up 10 to 15 passengers per trip at this point, some of whom are transferees from MDT buses.

When BCT eliminated route deviations by pulling buses out of neighborhoods and putting them on arterial roads, it met some political resistance from users who did not want to walk farther to reach a bus stop. The political solution to this problem was the designation of some transit operating funds to support community circu- 
lators, small buses that wander through neighborhoods, taking residents to nearby destinations and to stops on the mainline BCT routes. There are many local governments within Broward County, and evidently the local governments determine how to run the circulators in their jurisdictions. Our agency contact person stated that almost all of the patronage growth for BCT has been on the mainline routes on the arterial roads.

The left panel of Map 3 shows BCT's route structure in 2006 in relation to employment density in the county. The dispersal of employment sites throughout the county is readily apparent. All employment sites have gridded transit routes passing them. Residents living in most parts of the county can reach employment wherever it is located by using buses running in straight lines along arterial roads.
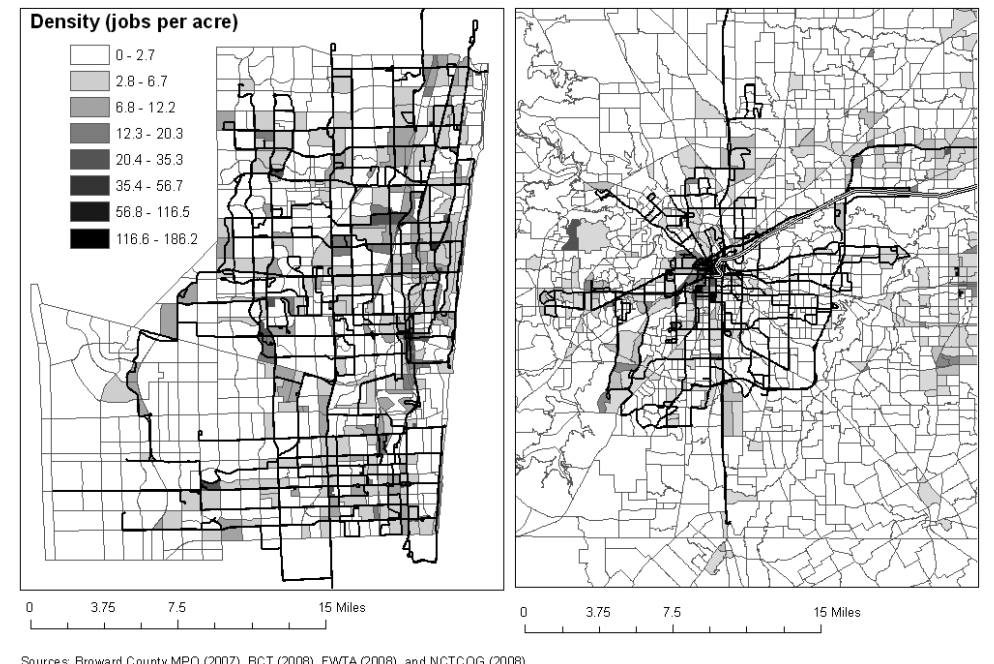

\section{Map 3. BCT Serves Many Destinations; The T Serves One Destination Well Transit Development in Tarrant County}

The dominance of the $\mathrm{Ft}$. Worth central business district over a long period of time and differences in funding mechanisms for transit between Texas and Florida have influenced The $T$ to evolve very differently than Broward County Transit. Streetcar lines and the Ft. Worth CBD grew hand-in-hand during the early 20th century, with streetcars extending out to suburbs from the CBD in the classic radial pattern. Through the transition from streetcar to bus and to the present day, this pattern of organizing transit routes has not changed (although it has been added to), even though employment and residents have decentralized throughout the region since auto ownership began rising rapidly after World War I. 
Finance also affects the pattern of transit development in Florida and Texas. As a County department, BCT receives subsidies from the County in sufficient magnitude to allow it to serve all of those parts of the county that are urbanized. The Florida Department of Transportation (FDOT) also provides some transit operating support through its gas tax. Financing is more difficult for The $T$ and restricts the territory that it can serve. There is no state operating support for transit in Texas, where local sales tax revenues provide the primary source of subsidy for transit operating deficits. Texas transit systems must appeal to individual communities for sales tax revenues, but Texas law imposes a sales tax cap on communities of 8.25 percent. Many communities already were at the limit before transit agencies approached them for funding. If a community chooses not to provide sales tax funding for transit, it gets no service. Because The $T$ historically served the city of Ft. Worth and was a City department before becoming an authority in 1983, it receives tax support from the City (population today of about 700,000). At the time it became an authority, it received a dedicated $1 / 4$-cent sales tax from the City to support transit. The $T$ also receives support from the City of Richland (population 7,000). The City of Arlington (population 300,000), in contrast, does not provide sales tax funding to either The T or to DART; Arlington thus receives no transit service. Unfortunately, some of the largest employment concentrations and most rapid employment growth in Tarrant County are in Arlington. Thus, The T does not serve significant parts of the urbanized areas in Tarrant County.

The T's route structure today is largely radial in nature. The two most heavily-traveled routes operate in straight lines on arterial roads from one side of the city to the other, one north-south and the other east-west. These operate every 15 minutes during weekdays. The two routes intersect in the CBD at the Intermodal Transportation Center, where TRE also stops. Schedules are coordinated so that passengers may transfer in both directions between the two routes and with Trinity Rail trains. The outer ends of these routes serve transit centers from which community circulator routes fan. Again, connections are coordinated. Other routes wind through neighborhoods not served by the first two routes on their way to the CBD. Some operate every 30 minutes; others operate hourly. A major route was implemented relatively recently and operates on arterial roads as it connects transit centers on the east, south, and west ends of the city. This belt route, which operates every 30 minutes, does not serve the CBD but does serve malls. It is the third most-heavily patronized of The T's routes, and its patronage has been growing briskly. During peak hours, seven express buses operate from outer neighborhoods and transit centers to the CBD. Most express routes consist of a handful of trips in the peak direction during the peak hours. In 
addition to regular route services, The T operates vans during shift changes between some major employment centers (particularly in the north) and transit centers.

The right panel of Map 3 shows The T's route structure in 2006 in relationship to the distribution of employment in Tarrant County. Although Ft. Worth is a central business district, employment is widely scattered throughout the county. While radial routes of The T pass by many of the suburban centers, residents in many parts of Tarrant County cannot reach the jobs without first traveling out of direction to the CBD transfer center, transferring, and then riding back out into the suburbs in another direction. There also are major job concentrations that routes of The $T$ do not serve at all. Those in Arlington are along the eastern border of Tarrant County.

\section{Comparative Transit Performance}

Operating statistics for both systems showing performance from 1984 through 2006 and are summarized in Table 1. BCT has been more generously funded than The $\mathrm{T}$, and this is apparent in Table 1 in the amount of service provided, measured as revenue miles. A revenue mile is a bus running one mile in revenue service. In $1984, B C T$ operated slightly more than twice the revenue miles that The T operated. By 2006, BCT operated almost four times as many revenue miles as The $T$.

Often times, a system that provides much more service than another will be less productive, because it has saturated the market. This is not the case of BCT compared to The T. Service productivity measures the average number of passengers on board the bus at any given time. For much of the period, BCT buses were 1.5 times to 2 times as full as The T buses, although productivity for The T increased rapidly in 2005 and 2006, greatly narrowing the gap.' Figure 2 visually shows the productivity trends. We suspect that the greater productivity of BCT buses arises from the wider array of destinations that they serve relatively well.

As a consequence of offering four times as much service combined with the greater productivity of each mile of service, BCT penetrates the travel market in its area to a much greater extent than does The T. We denote the penetration of the travel market as riding habit, a term that the U.S. transit industry once used to this purpose. Historically, the transit industry defined riding habit as revenue passengers divided by population served. The industry no longer collects the statistic of revenue passengers (it is now calls linked trips), so we define the term as revenue passenger miles divided by population served. We also define the population served as that in the county. Even if the transit system does not serve all of the county, 
Table 1. BCT and The T Bus Service, 1984-2006

\begin{tabular}{|c|c|c|c|c|c|c|}
\hline \multicolumn{6}{|c|}{ Broward County Transit (BCT) } & \multirow{2}{*}{$\begin{array}{c}\text { Operating } \\
\text { Expense per } \\
\text { Passenger } \\
\text { Mile (2006\$) }\end{array}$} \\
\hline Year & Population & Miles & Miles & Habit & Productiviity & \\
\hline 1984 & $1,110,862$ & $72,755,935$ & $6,771,663$ & 65.50 & 10.74 & $\$ 0.50$ \\
\hline 1985 & $1,132,921$ & $84,264,996$ & $7,437,699$ & 74.38 & 11.33 & $\$ 0.49$ \\
\hline 1986 & $1,154,494$ & $78,991,384$ & $8,375,628$ & 68.42 & 9.43 & $\$ 0.59$ \\
\hline 1987 & $1,180,921$ & $61,379,078$ & $8,875,849$ & 51.98 & 6.92 & $\$ 0.78$ \\
\hline 1988 & $1,208,428$ & $75,028,484$ & $8,910,748$ & 62.09 & 8.42 & $\$ 0.68$ \\
\hline 1989 & $1,233,040$ & $67,589,568$ & $8,973,206$ & 54.82 & 7.53 & $\$ 0.80$ \\
\hline 1990 & $1,263,301$ & $81,992,838$ & $8,947,336$ & 64.90 & 9.16 & $\$ 0.68$ \\
\hline 1991 & $1,296,261$ & $81,118,030$ & $9,120,846$ & 62.58 & 8.89 & $\$ 0.68$ \\
\hline 1992 & $1,325,375$ & $97,622,366$ & $9,134,271$ & 73.66 & 10.69 & $\$ 0.55$ \\
\hline 1993 & $1,372,526$ & $96,753,748$ & $9,111,227$ & 70.49 & 10.62 & $\$ 0.56$ \\
\hline 1994 & $1,412,641$ & $103,822,086$ & $9,662,692$ & 73.50 & 10.74 & $\$ 0.53$ \\
\hline 1995 & $1,447,124$ & $111,004,429$ & $9,767,690$ & 76.71 & 11.36 & $\$ 0.50$ \\
\hline 1996 & $1,481,333$ & $109,542,370$ & $9,832,227$ & 73.95 & 11.14 & $\$ 0.51$ \\
\hline 1997 & $1,522,179$ & $110,289,977$ & $9,801,046$ & 72.46 & 11.25 & $\$ 0.50$ \\
\hline 1998 & $1,560,649$ & $111,568,312$ & $10,410,633$ & 71.49 & 10.72 & $\$ 0.53$ \\
\hline 1999 & $1,594,130$ & $114,736,758$ & $10,598,450$ & 71.97 & 10.83 & $\$ 0.51$ \\
\hline 2000 & $1,623,018$ & $119,986,652$ & $12,013,192$ & 73.93 & 9.99 & $\$ 0.53$ \\
\hline 2001 & $1,670,494$ & $137,200,475$ & $13,245,365$ & 82.13 & 10.36 & $\$ 0.51$ \\
\hline 2002 & $1,703,998$ & $142,999,966$ & $14,687,845$ & 83.92 & 9.74 & $\$ 0.53$ \\
\hline 2003 & $1,728,336$ & $153,883,282$ & $15,392,404$ & 89.04 & 10.00 & $\$ 0.55$ \\
\hline 2004 & $1,753,000$ & $162,009,619$ & $15,314,924$ & 92.42 & 10.58 & $\$ 0.54$ \\
\hline 2005 & $1,777,638$ & $162,688,826$ & $15,760,508$ & 91.52 & 10.32 & $\$ 0.53$ \\
\hline 2006 & $1,787,636$ & $168,100,759$ & $16,013,518$ & 94.04 & 10.50 & $\$ 0.53$ \\
\hline \multicolumn{6}{|c|}{ Fort Worth Transportation Authority (The T) } & $\begin{array}{c}\text { Operating } \\
\text { Expense per }\end{array}$ \\
\hline Year & Population & Miles & Miles & $\begin{array}{l}\text { Riding } \\
\text { Habit }\end{array}$ & $\begin{array}{c}\text { Service } \\
\text { Productiviity }\end{array}$ & $\begin{array}{l}\text { Passenger } \\
\text { Mile }(2006 \$)\end{array}$ \\
\hline 1984 & $1,001,836$ & $25,996,998$ & $3,146,409$ & 25.95 & 8.26 & $\$ 0.62$ \\
\hline 1985 & $1,043,207$ & $23,787,695$ & $3,826,627$ & 22.80 & 6.22 & $\$ 0.75$ \\
\hline 1986 & $1,083,641$ & $27,286,469$ & $3,729,784$ & 25.18 & 7.32 & $\$ 0.72$ \\
\hline 1987 & $1,116,110$ & $26,077,602$ & $3,513,866$ & 23.36 & 7.42 & $\$ 0.73$ \\
\hline 1988 & $1,133,193$ & $21,543,916$ & $3,596,248$ & 19.01 & 5.99 & $\$ 0.84$ \\
\hline 1989 & $1,149,530$ & $31,693,345$ & $3,606,597$ & 27.57 & 8.79 & $\$ 0.60$ \\
\hline 1990 & $1,177,220$ & $48,894,085$ & $4,217,180$ & 41.53 & 11.59 & $\$ 0.39$ \\
\hline 1991 & $1,205,887$ & $41,969,177$ & $4,597,108$ & 34.80 & 9.13 & $\$ 0.50$ \\
\hline 1992 & $1,225,543$ & $27,569,034$ & $4,516,312$ & 22.50 & 6.10 & $\$ 0.82$ \\
\hline 1993 & $1,243,884$ & $32,344,667$ & $4,827,258$ & 26.00 & 6.70 & $\$ 0.73$ \\
\hline 1994 & $1,270,639$ & $34,797,556$ & $4,992,711$ & 27.39 & 6.97 & $\$ 0.69$ \\
\hline 1995 & $1,294,453$ & $30,474,382$ & $4,993,480$ & 23.54 & 6.10 & $\$ 0.77$ \\
\hline 1996 & $1,323,207$ & $30,275,663$ & $4,754,570$ & 22.88 & 6.37 & $\$ 0.73$ \\
\hline 1997 & $1,355,318$ & $28,706,617$ & $4,940,493$ & 21.18 & 5.81 & $\$ 0.82$ \\
\hline 1998 & $1,388,366$ & $24,962,373$ & $4,597,262$ & 17.98 & 5.43 & $\$ 0.92$ \\
\hline 1999 & $1,422,372$ & $25,373,686$ & $4,657,887$ & 17.84 & 5.45 & $\$ 1.00$ \\
\hline 2000 & $1,446,219$ & $27,266,081$ & $4,740,854$ & 18.85 & 5.75 & $\$ 0.96$ \\
\hline 2001 & $1,488,780$ & $30,617,583$ & $4,868,114$ & 20.57 & 6.29 & $\$ 1.00$ \\
\hline 2002 & $1,525,317$ & $27,632,150$ & $4,750,862$ & 18.12 & 5.82 & $\$ 1.17$ \\
\hline 2003 & $1,557,128$ & $24,048,649$ & $3,923,945$ & 15.44 & 6.13 & $\$ 1.14$ \\
\hline 2004 & $1,587,019$ & $21,537,919$ & $3,879,328$ & 13.57 & 5.55 & $\$ 1.18$ \\
\hline 2005 & $1,620,479$ & $29,106,436$ & $4,459,345$ & 17.96 & 6.53 & $\$ 0.89$ \\
\hline 2006 & $1,671,295$ & $31,615,080$ & $4,063,813$ & 18.92 & 7.78 & $\$ 0.85$ \\
\hline
\end{tabular}

Sources: FDOT (2008), U.S. Census Bureau (2008) 


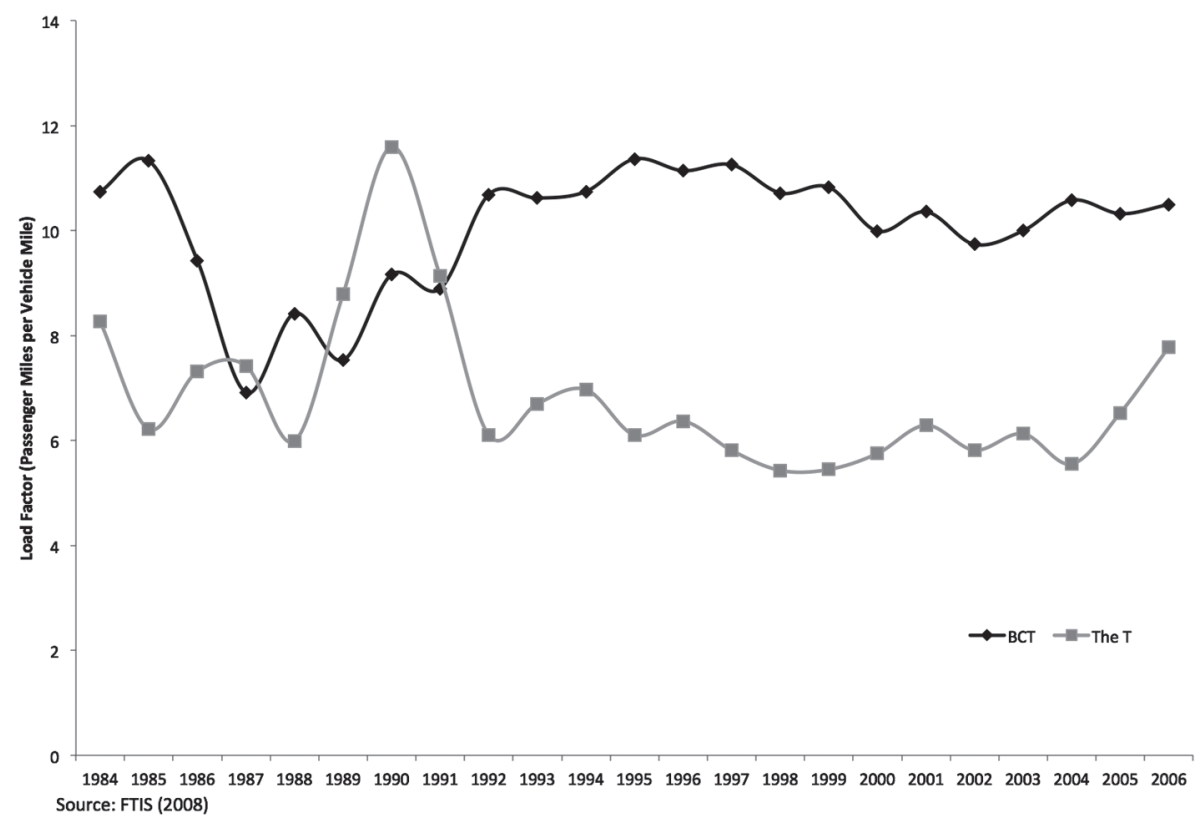

Figure 2. Productivity (Passenger Miles per Bus Mile, 1984-2006)

residents that it does serve want to reach destinations throughout the county, so county population is a fair measure. On that basis, we see in Figure 3 that riding habit now is nearly five times greater in Broward County than it is in Tarrant County. We also see in Figure 4 that because of its greater productivity, BCT spends significantly less to move a passenger one mile than does The $T$.

To gain additional insight into the relative performance of the two transit systems, we examined in Table 2 the performance of their various categories of services. At the time we collected data, BCT distinguished only two categories of service: the gridded fixed-bus routes operating on arterial roads and community bus services circulating through neighborhoods. The top panel of Table 5 shows that the fixed routes are far more productive than are the community routes while accounting for about 15 times more patronage than the community services. Moreover, our agency contact person for BCT stated that all of the patronage growth for the system has been accounted for by the gridded mainline routes on arterial roads. 


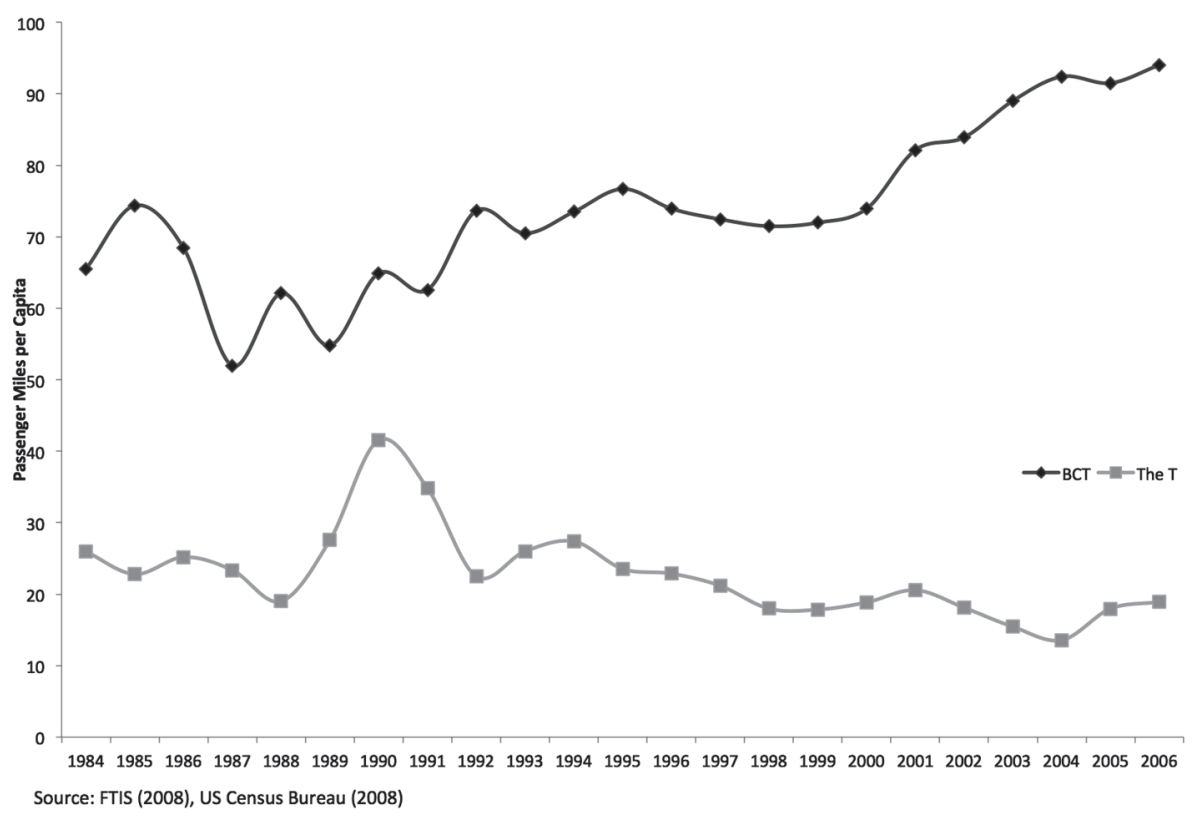

Figure 3. Riding Habit (Passenger Miles per Capita, 1984-2006)

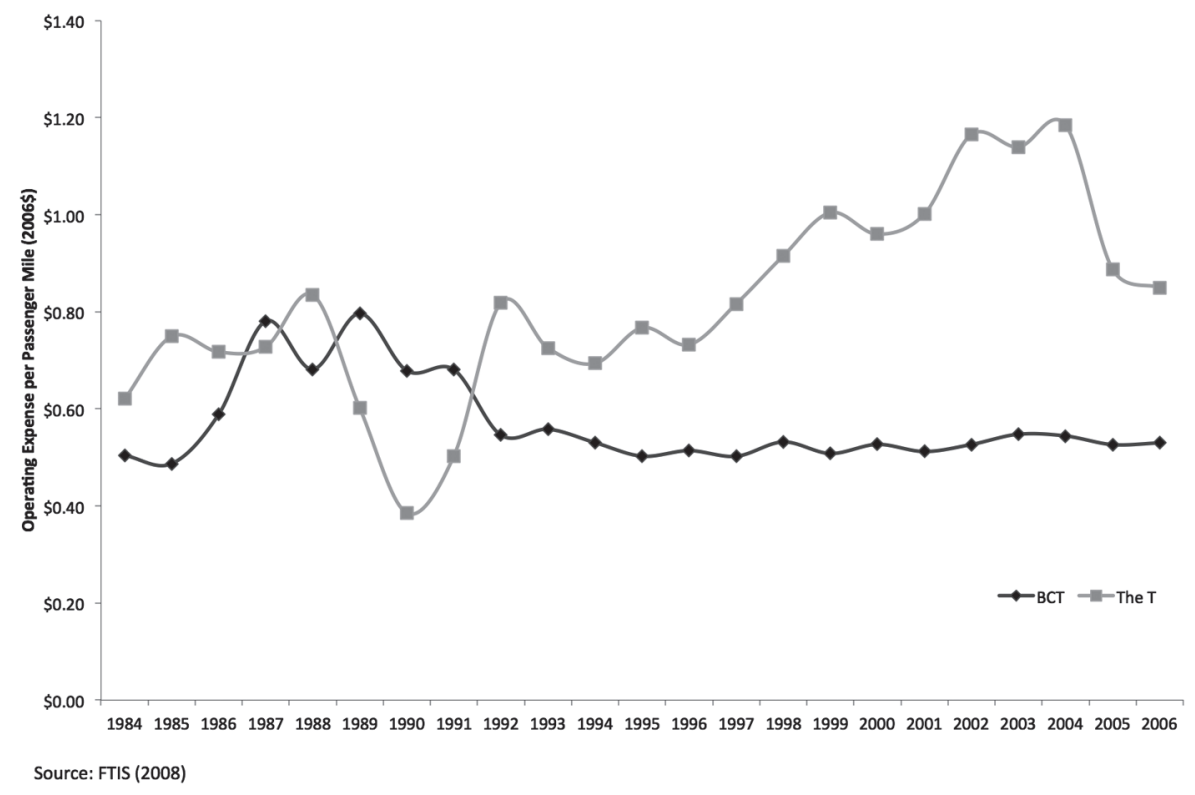

Figure 4. Efficiency (Cost per Passenger Mile, 1984-2006) 
Table 2. Transit Performance by Service Type, BCT and The T

Broward County Transit (BCT)

\begin{tabular}{|c|c|c|c|c|}
\hline \multirow[b]{2}{*}{ Service Type } & \multirow[b]{2}{*}{$\begin{array}{c}\text { Monthly } \\
\text { Boardings }\end{array}$} & \multirow{2}{*}{$\begin{array}{c}\text { Monthly } \\
\text { Revenue } \\
\text { Hours }\end{array}$} & \multicolumn{2}{|c|}{ Boardings per Revenue Hour } \\
\hline & & & Average & $\begin{array}{c}\text { Median } \\
\text { Route }\end{array}$ \\
\hline Fixed-Route Bus & $3,209,681$ & 87,317 & 36.76 & 31.72 \\
\hline Community Bus & 214,085 & 21,183 & 10.11 & 8.84 \\
\hline
\end{tabular}

Fort Worth Transportation Authority (The T)

\begin{tabular}{lcccc}
\hline & Monthly & Monthly & Boardings per Revenue Hour \\
\cline { 4 - 5 } Service Type & Roardings & Rours & Average & $\begin{array}{c}\text { Median } \\
\text { Route }\end{array}$ \\
\hline Radial Routes & 355,389 & 20,036 & 17.74 & 13.72 \\
Crosstown Routes & 67,247 & 4,562 & 14.74 & 10.61 \\
Express Routes & 11,372 & 1,023 & 11.12 & 12.94 \\
Feeder Routes & 59,313 & 4,657 & 12.74 & 8.54 \\
Circulator Routes & 15,798 & 675 & 23.39 & 7.73 \\
All CBD-serving Routes & 366,360 & 21,311 & 17.19 & 13.09 \\
All Non-CBD Routes & 142,759 & 9,642 & 14.81 & 11.78 \\
All Fixed-Route Bus & 509,119 & 30,953 & 16.45 & 12.81 \\
\hline
\end{tabular}

Sources: BCT (2008), FWTA (2008)

Note: BCT and The T statistics are for January 2008

The T operates a wider array of services. Our examination of the performance of individual routes shows only three routes with heavy patronage. The well-performing routes include the east-west and north-south routes that intersection in the $\mathrm{CBD}$ and the belt line that connects the east and south suburban transit centers with suburban destinations while intersecting with all routes operating to the CBD from the east, south, and west. These three routes account for just more than 50 percent of the patronage of the fixed-route system in FY 2008. Other radial routes, crosstown routes, circulator routes, and express routes have much lower patronage. The seven express routes contributed only 2.7 percent of system patronage. Table 2 reflects the widely differing performance level in each category of service by showing large differences between mean and median performance in most categories. The mean is heavily weighted by the one or two routes that do well in 
the crosstown and radial categories, respectively, whereas the median reflects the performance of the remaining routes in each category. As in Broward County, in Tarrant County the routes that perform the best are those that operate in relatively straight lines on major arterial roads, serving a relatively large array of destinations.

\section{Conclusions}

According to much of the literature, Tarrant County offers a better built environment to support greater transit demand than does Broward County. Tarrant County has a traditional central business district and surrounding inner suburbs whose form took shape when streetcars were the dominant urban transport mode. While most of Tarrant County's growth took place after the automobile became the dominant form of transportation, there exists in Tarrant County a core whose land uses were shaped around transit and that presumably today offers a hospitable environment in which transit can prosper. Planners for The T have taken advantage of this situation and have continued to focus transit routes as connectors between suburban residences and CBD jobs. They further have enhanced transit service by overlaying a network of express buses between outlying neighborhoods and the CBD during week day peak travel periods.

In contrast, no such central business district existed in Broward County, which consisted during the pre-auto era of very small towns strung out along a railroad line. The urban form of Broward County began to take shape later, long after the private automobile was the dominant form of urban transportation. No central business district then emerged. Instead, employment as it grew in Broward County scattered about the county. Private transit service that survived into the 1970 s connected residential areas with the small downtown of Ft. Lauderdale, but the private service attracted few riders, prompting planners to think of another way of serving the market when the county took over the service.

So, based on urban form, we would expect transit to perform much better in Tarrant County than in Broward. And yet, just the opposite has transpired. Transit in Broward County carries almost 400 percent more ridership per capita than does transit in Tarrant County, while each bus mile operated in Broward County carries about 35 percent more passengers.

Part of the explanation for this unexpected result derives from organization and funding. As a county-wide agency, Broward County Transit is compelled to think of ways of serving the entire county, not just the small downtowns. The $T$, in con- 
trast, has its organization roots in the city of Ft. Worth, and other jurisdictions in the county do not want to pay for service provided by The T. Consequently, The T thinks of its market much differently than BCT.

We think that it is the difference in thinking that accounts for the rest of the difference in performance between the two systems. Large areas of employment in Tarrant County remain un-served by transit, and much of the suburban employment that is served is done so ineffectively because of circuitous routing. The T serves the Ft. Worth CBD well but other possible destinations less well. In contrast, BCT with its grid route structure on major arterial roads serves most destinations tolerably directly. This contrast suggests that how a transit system uses its route structure to connect origins and destinations is more important to developing ridership than is the design of the origins and destinations.

This is not to say that policies for concentrating development around stops at both the origin and destination of transit trips would not boost transit ridership. Making the walk to transit shorter and more attractive without sacrificing route speeds or headways to accomplish the shorter walks undoubtedly would increase ridership markedly. One way for shortening walks is through transit oriented development (TOD). Over time, if the large-scale application of TODs can accommodate population and employment growth in smaller urban regions than otherwise would be the case, transit ridership would increase substantially. But, currently, transit systems can increase ridership substantially by restructuring routes to make more of the region's employment accessible by transit.

\section{Endnotes}

${ }^{1}$ The improvement in productivity for The $\mathrm{T}$ is not the result of more passengers riding the system, but the result of passengers riding longer distances. We verified with our contact that express bus riding is not increasing and that the figures do not include TRE riding, so we do not have an explanation for what is causing the recent increases in trip length.

\section{Acknowledgments}

The authors wish to thank the Florida Department of Transportation and the Mineta Transportation Institute for grants that made this paper possible. They also wish to thank the staffs of the Ft. Worth Transit Authority (The T), the North 
Central Texas Council of Governments, and Broward County Transit (BCT) for interviews and data. We remain responsible, however, for possible errors and omissions as well as for opinion expressed in this document.

\section{References}

Broward County MPO. 2007. Employment by traffic analysis zone. Provided by Broward County MPO staff.

Broward County Transit (BCT). 2008. Transit route shapefile. Provided by BCT staff.

Brown, J., and D. Neog. 2007. Reexamining the link between urban structure and transit ridership in the United States. Discussion paper. Florida Planning and Development Lab, Florida State University, Tallahassee.

Brown, J., and G. Thompson. 2008. The relationship between transit ridership and urban decentralization: Insights from Atlanta. Urban Studies 45: 1119-1139.

Brown, J., and G. Thompson. 2009. The influence of service planning decisions on rail transit success or failure. Mineta Transportation Institute, San Jose, CA.

Ferreri, M. 1992. Comparative costs. In Gray, G. and L. Hoel, eds., Public Transportation, 2nd ed. Prentice Hall, Englewood Cliffs, NJ .

Florida Department of Transportation. 2008. Florida transit information system. http://www.ftis.org/INTDAS/tableflat.aspx, downloaded Summer 2008.

Fort Worth Transportation Authority (The T). 2008. Transit route shapefile. Provided by The T staff.

Gomez-lbanez, J. 1996. Big-city transit ridership, deficits, and politics: Avoiding reality in Boston. Journal of the American Planning Association 62: 30-50.

Hendrickson, C. 1986. A note on trends in transit commuting in the United States relating to employment in the central business district. Transportation Research Part A 20: 33-37.

Meyer, J., and J. Gomez-lbanez. 1981. Autos, Transit, and Cities. Harvard University Press, Cambridge, MA.

Miami-Dade Transit. 2007. Miami MSA transit route shapefiles. Provided by MDT staff. 
Mierzejewski, E., and W. Ball. 1990. New findings on factors related to transit use. ITE Journal 60 (2): 34-39.

North Central Texas Council of Governments. 2007. Year 2007 Dallas-Fort Worth MSA transit system route shapefiles. Provided by NCTCOG staff.

North Central Texas Council of Governments. 2008. Employment by traffic analysis zone. Provided by NCTCOG staff.

Pisarski, A. 1996. Commuting in America II. Eno Foundation, Washington, D.C.

Taylor, B. 1991. Unjust equity: An examination of California's Transportation Development Act. Transportation Research Record 1297: 85-92.

U.S. Census Bureau. 2008. Population by county: 1984-2006, constructed from 1980s Intercensal Population Estimates, 1990s Intercensal Population Estimates, and 2001-2006 Population Estimates Data. http://www.census.gov

\section{About the Authors}

JefFReY R. BRown (jrbrown3@fsu.edu) is Associate Professor and Director of the Master's Program in the Department of Urban and Regional Planning at Florida State University. His research interests include the early professionalization of transportation planning, the changing nature of street and highway planning in the United States, transportation finance, and the relevance of different service strategies for making public transit more successful in decentralized urban areas.

Gregory L. Thompson (glthompson@fsu.edu) is a Professor with the Department of Urban and Regional Planning at Florida State University. His research interests involve understanding the role of public transportation in auto-dominated society using historical case study and quantitative methods. 